\title{
The crystal structure of $\mathrm{Ba}_{3} \mathrm{Nb}_{2} \mathrm{O}_{8}$ revisited: a neutron diffrac- tion and solid state NMR study.
}

\author{
Eve J. Wildman ${ }^{\dagger}$, Abbie C. Mclaughlin ${ }^{\dagger}$, James F. Macdonald ${ }^{\ddagger}$, John V. Hanna ${ }^{\ddagger}$ and Janet M. S. \\ Skakle ${ }^{\dagger, \S^{*}}$ \\ ${ }^{\dagger}$ Department of Chemistry, School of Natural E Computing Sciences, University of Aberdeen, Meston Walk, Aberdeen \\ $A B 243 U E, U K$ \\ ${ }^{\ddagger}$ Department of Physics, University of Warwick, Gibbet Hill Rd., Coventry CV4 7AL UK \\ ${ }^{\S}$ Department of Physics, School of Natural E Computing Sciences, University of Aberdeen, Meston Walk, Aberdeen \\ $A B 243 U E, U K$.
}

\begin{abstract}
The structure of $\mathrm{Ba}_{3} \mathrm{Nb}_{2} \mathrm{O}_{8}$ has been investigated using high resolution neutron powder diffraction. Our results show that whilst the structure has some features in common with the ${ }_{9} \mathrm{R}$ perovskite and palmierite structures, it is a new and distinct structure. It is shown to follow a $(c h h)(h h c)(c h h)$ sequence with $\mathrm{BaO}_{3-\delta}$ packing layers and is a cation and aniondeficient $9 \mathrm{H}$ perovskite polytype. $\mathrm{Nb}$ atoms occupy octahedral sites with vacancies between hexagonal close-packed layers. Isolated, corner-sharing and face-sharing $\mathrm{Nb}-\mathrm{O}$ octahedra all occur within the unit cell. The identification of purely octahedral $\mathrm{Nb}$ is supported by solid state ${ }^{33} \mathrm{Nb}$ wideline NMR measurements. A two-component line shape was detected: a narrow featureless resonance with an isotropic chemical shift of $\delta_{\text {iso }}-928 \pm 5 \mathrm{ppm}$ consistent with regular Nb octahedra, and a much broader featureless resonance with an approximate isotropic chemical shift in the range $\delta_{\text {iso }} \sim-944--937 \pm 10$ ppm consistent with $\mathrm{Nb}$ octahedra influenced by $\mathrm{O}$ vacancies. These are both characteristic of six-fold oxo-coordinated $\mathrm{Nb}$ environments. The highly distorted octahedral environments in $\mathrm{Ba}_{3} \mathrm{Nb}_{2} \mathrm{O}_{8}$ make it a potential candidate for dielectric and photocatalytic applications.
\end{abstract}

\section{INTRODUCTION}

The sub-solidus binary system $\mathrm{BaO}-\mathrm{Nb}_{2} \mathrm{O}_{5}$ contains a number of complex and interesting phases, with several known hexagonal perovskite-derived polytypes lying in the $\mathrm{BaO}$ rich region'. One example is the compound $\mathrm{Ba}_{4} \mathrm{Nb}_{2} \mathrm{O}_{9}$ which has been shown to exhibit a number of different polymorphs $^{2-4}$. The complex nature of these polymorphs, their inter-relationship and the ability of the material to absorb and desorb water results in mixed oxide, protonic and electronic conduction over a wide temperature range ${ }^{3,4}$. Complex oxides of niobium (and their tantalate analogues) have also received much attention within the field of photocatalysis as many phases possess stability to photocorrosion due to the favourable location of the conduction band ${ }^{5,6}$.

Hexagonal $\mathrm{Ba}_{5} \mathrm{Nb}_{4} \mathrm{O}_{15}$ lies close to $\mathrm{Ba}_{4} \mathrm{Nb}_{2} \mathrm{O}_{9}$, but is a crystallographically simpler system with corner-sharing $\mathrm{NbO}_{6}$ forming perovskite-like blocks, 4 octahedra in thickness, perpendicular to the c-axis of the primitive hexagonal cell ${ }^{1,7,8}$. There are two crystallographically distinct $\mathrm{Nb}$ sites, with one showing considerable distortion compared with the other, as determined by both powder and single crystal studies ${ }^{1,9}$. As a result of this distortion, $\mathrm{Ba}_{5} \mathrm{Nb}_{4} \mathrm{O}_{15}$, exhibits excellent microwave dielectric properties with a high relative permittivity $\left(\varepsilon_{\mathrm{r}}\right)$, high quality factor $(\mathrm{Q})$ and a low temperature coefficient of resonator frequency $\left(\tau_{f}\right)^{9,10}$.

Conflicting reports exist for the crystal structure of $\mathrm{Ba}_{3} \mathrm{Nb}_{2} \mathrm{O}_{8}$, which lies between $\mathrm{Ba}_{4} \mathrm{Nb}_{2} \mathrm{O}_{9}$ and $\mathrm{Ba}_{5} \mathrm{Nb}_{4} \mathrm{O}_{15}$ in the phase diagram. The stoichiometry of $\mathrm{Ba}_{3} \mathrm{Nb}_{2} \mathrm{O}_{8}$ is typical of the palmierite family $\left(\mathrm{A}_{3} \mathrm{~B}_{2} \mathrm{O}_{8}{ }^{11}\right)$, such as $\mathrm{Ba}_{3} \mathrm{~V}_{2} \mathrm{O}_{8}$ and $\mathrm{Ba}_{3} \mathrm{P}_{2} \mathrm{O}_{8}{ }^{12,13}$. Palmierites crystallise in space group $R \overline{3} m$ and are structural derivatives of the ${ }_{9} \mathrm{R}$ perovskite $\left(\mathrm{ABO}_{3}\right)$, yet incorporate tetrahedral co-ordination of the $\mathrm{B}$-site cation instead of octahedral. The ${ }_{9} \mathrm{R}$ perovskite comprises $(h h c)_{3}$ stacking layers; the cubic layers of which are transformed from $\mathrm{AO}_{3}$ to oxygen deficient $\mathrm{AO}_{2}$ layers in order to form the palmierite structure ${ }^{14}$. This conversion gives rise to tetrahedrally coordinated B atoms, and is most interesting as it results in an oxygen and cation deficient "perovskite- 
like" crystal structure which has been known to accommodate both cation and oxide ion conductivity ${ }^{15-17}$.

Single crystal and powder X-ray diffraction studies report that $\mathrm{Ba}_{3} \mathrm{Nb}_{2} \mathrm{O}_{8}$ adopts the aforementioned palmierite structure $^{1,18,19}$ with $\mathrm{Nb}$ occupying discrete tetrahedral units but with a very small amount (7.5\%) of $\mathrm{Nb}$ occupying octahedral sites. However, contradictory results were obtained by high resolution electron microscopy (HREM) and Raman spectroscopy ${ }^{20,21}$, which instead suggest a $9 \mathrm{H}$ polytype containing palmierite/perovskite slabs with a 1:1 ratio of octahedral and tetrahedral sites.

Although modelling of the HREM images could not fully determine the structure, two models derived from primitive hexagonal unit cells were suggested ${ }^{21}$. These were used as the basis for experimental analysis and it was concluded that neither model was adequate so that instead, an intermediate between the two was a more likely interpretation.

The importance of fully characterising the crystal structure of $\mathrm{Ba}_{3} \mathrm{Nb}_{2} \mathrm{O}_{8}$ has been emphasised recently by the discovery of oxide ion conductivity in the related hexagonal phase $\mathrm{Ba}_{3} \mathrm{MoNbO}_{8.5}{ }^{22}$. Its unique crystal structure is essentially a hybrid of the palmierite and ${ }_{9} \mathrm{R}$ perovskite unit cells, containing a disordered arrangement of $(\mathrm{Nb} / \mathrm{Mo}) \mathrm{O}_{6}$ octahedra and $(\mathrm{Nb} / \mathrm{Mo}) \mathrm{O}_{4}$ tetrahedra. A bulk conductivity of $2.2 \times 10^{-3} \mathrm{~S} \mathrm{~cm}^{-1}$ is observed at $600{ }^{\circ} \mathrm{C}$, which is comparable to other well-known ionic conductors such as LAMOX and BIMEVOX ${ }^{23,24}$. Resistivity and transport measurements in various atmospheres suggest that oxide ions are the dominant charge carriers in $\mathrm{Ba}_{3} \mathrm{MoNbO}_{8.5}$; with conduction pathways facilitated and enhanced by several structural factors as follows. High resolution neutron diffraction analysis indicates large anisotropic thermal displacement parameters for $\mathrm{Mo} / \mathrm{Nb}$ cations which occupy highly distorted polyhedra. This acts to stabilise the disordered structure and, in addition to the flexible nature of the cation coordination environment, provides a low energy migration pathway for conducting ions. Considering that both $\mathrm{Ba}_{3} \mathrm{MoNbO}_{8.5}$ and $\mathrm{Ba}_{3} \mathrm{Nb}_{2} \mathrm{O}_{8}$ appear to be cation and anion deficient perovskite derivatives, with clear chemical similarities, it is important that the structure of $\mathrm{Ba}_{3} \mathrm{Nb}_{2} \mathrm{O}_{8}$ is fully understood. Therefore, in this study, the crystal structure of $\mathrm{Ba}_{3} \mathrm{Nb}_{2} \mathrm{O}_{8}$ has been determined from the Rietveld refinement of high resolution neutron diffraction data and describes a unit cell distinct from palmierite and all other 9-layered perovskite derivatives. The local $\mathrm{Nb}$ environment was further analysed using high field ${ }^{93} \mathrm{Nb}$ solidstate nuclear magnetic resonance spectroscopy (NMR).

\section{EXPERIMENTAL SECTION}

Synthesis: Stoichiometric amounts of $\mathrm{BaCO}_{3}$ (Aldrich, $99+\%$ ) and $\mathrm{Nb}_{2} \mathrm{O}_{5}$ (Aldrich, 99.99\%) were ground in an agate pestle and mortar followed by calcination in air for $16 \mathrm{~h}$ at $900^{\circ} \mathrm{C}$. The powder was then re-ground, pelletized, covered with sacrificial powder of the same composition and placed in an alumina crucible which was then heated at $1300^{\circ} \mathrm{C}$ for $76 \mathrm{~h}$.
X-ray and Neutron Powder Diffraction: Samples were initially characterised by powder X-ray diffraction data using a Bruker D8 Advance diffractometer with twin Göbel mirrors and $\mathrm{CuK}_{\alpha}$ radiation $(\lambda=1.5418 \AA)$. Data was collected over the range $10^{\circ}<2 \theta<100^{\circ}$ with a step size of $0.02^{\circ}$.

Time-Of-Flight (TOF) neutron diffraction patterns were recorded on the high intensity, high resolution diffractometer GEM at the pulsed neutron source ISIS facility, Rutherford Appleton Laboratory, UK ${ }^{25}$. Due to the possibility of decomposition of the phase over a few days, a $5 \mathrm{~g}$ sample was stored under $\mathrm{N}_{2}$ in a sealed tube prior to measurement. The powder was extracted and loaded into an $8 \mathrm{~mm}$ vanadium can and data were obtained at room temperature. Rietveld refinement was carried out using the GSAS package $^{26}$ with the EXPGUI interface ${ }^{27}$ using data collected over the time-of-flight range $3000-18000 \mu \mathrm{sec}$ in the highest resolution, backscattering detectors.

Solid State NMR: Samples were synthesised and immediately sealed in evacuated silica tubes for transport for NMR measurements. The tubes were broken prior to measurement. Static broadline ${ }^{93} \mathrm{Nb}$ NMR data were acquired at ambient temperatures on 9.4 and $18.8 \mathrm{~T}$ systems using Bruker DSX-40o and Varian CMX Infinity-8oo spectrometers operating at ${ }^{93} \mathrm{Nb}$ Larmor frequencies of 97.83 and 195.54 MHz, respectively. These measurements were performed using a Bruker $5 \mathrm{~mm}$ static horizontal solenoid design probe (at 9.4 T), and a home-built, balanced-circuit design $7.5 \mathrm{~mm}$ static horizontal solenoid probe (at $18.8 \mathrm{~T}$ ). All static ${ }^{93} \mathrm{Nb}$ data were acquired with the solid echo $\theta-\tau$ - $\theta-\tau$ - (acquire) $(\theta \approx \pi / 4)$ experiment with an extended phase cycle to capture undistorted echoes with minimal influences from residual echo tails and finite pulse widths ${ }^{28,29}$. 'Non-selective' (solution) $\pi / 2$ pulse widths of 8 - $10 \mu$ s were calibrated on a saturated $\mathrm{K}\left[\mathrm{NbCl}_{6}\right] / \mathrm{CH}_{3} \mathrm{CN}$ solution from which 'selective' (solid) $\theta$ pulses of $0.8-1.0 \mu \mathrm{s}$ were employed in the solid echo measurements. The $\tau$ delay was $20 \mu$ s and the relaxation delay between transients was $2 \mathrm{~s}$. Simulation of the featureless ${ }^{93} \mathrm{Nb}$ resonances associated with the disordered $\mathrm{Ba}_{3} \mathrm{Nb}_{2} \mathrm{O}_{8}$ phase was undertaken using the DMFIT simulation software package ${ }^{30}$.

FTIR: Fourier transform infrared spectroscopy (FTIR) spectra were measured from 400 scans at $4 \mathrm{~cm}^{-1}$ resolution using a Nicolet 380 spectrometer, fitted with a diamond attenuated total reflectance (ATR) platform.

\section{RESULTS AND DISCUSSION Synthesis.}

It became apparent during initial attempts to obtain single phase $\mathrm{Ba}_{3} \mathrm{Nb}_{2} \mathrm{O}_{8}$ that following the synthesis steps reported in much of the previous literature resulted in an impure product, with second phases $\mathrm{Ba}_{5} \mathrm{Nb}_{4} \mathrm{O}_{15}$ and $\mathrm{Ba}_{4} \mathrm{Nb}_{2} \mathrm{O}_{9}$. It was thus found, however, that a sample of high purity could be obtained via two differing methods. Both processes involved the solid-state reaction of $\mathrm{BaCO}_{3}$ (Aldrich, 99+\%) and $\mathrm{Nb}_{2} \mathrm{O}_{5}$ (Aldrich, 99.99\%). The first 
method was as described above. A second method used a non-stoichiometric approach with a slight excess of $\mathrm{BaCO}_{3}$ (to account for volatilisation and thus without the need for sacrificial powder) combining $75.25 \% \mathrm{BaCO}_{3}$ with $24.75 \%$ $\mathrm{Nb}_{2} \mathrm{O}_{5}$ and heating to $1250^{\circ} \mathrm{C}$ for $48 \mathrm{~h}$; this also resulted in a phase-pure product. For the samples studied further here, the first method (covering a pellet with powder of the same composition) was used as this gave the most reproducible results and also meant that the stoichiometry was controlled.

\section{Powder Diffraction and FTIR.}

$\mathrm{X}$-ray powder diffraction data showed samples of $\mathrm{Ba}_{3} \mathrm{Nb}_{2} \mathrm{O}_{8}$ to be phase-pure and could be fully indexed on a hexagonal unit cell with lattice parameters $a=5.89 \AA, c=$ $20.94 \AA$; consistent with a 9-layered perovskite-derived structure. These values are noticeably different from 2 previous studies which describe phases with much larger unit cells $\left(a=6.0477 \AA, c=21.289 \AA^{1}, a=6.045 \AA\right.$ and $c=21.127$ $\left.\AA^{19}\right)$ but is reasonably consistent with the HREM study ( $a=$ $5.82 \AA, c=21.15 \AA)^{21}$. The difference of the unit cell volumes described in the literature may be a consequence of the airsensitive nature of $\mathrm{Ba}_{3} \mathrm{Nb}_{2} \mathrm{O}_{8}$, which does not appear to be accounted for in existing reports. With time, the sample decomposed and thus for XRPD samples were measured immediately. This is not unusual: a recent study on the mixed conductor, $\mathrm{Ba}_{4} \mathrm{Nb}_{2} \mathrm{O}_{9}{ }^{31}$, describes the uptake of carbonate onto vacant cation sites, replacing oxygen within the structure upon cooling. Fourier transform infrared (FTIR) spectroscopy measurements were performed on a sample of $\mathrm{Ba}_{3} \mathrm{Nb}_{2} \mathrm{O}_{8}$ at 24 hour intervals and clearly show the development of peaks attributable to increasing amounts of carbonate in the sample at $\sim 1430 \mathrm{~cm}^{-1}$ (Figure 1 inset). This suggests that interstitial carbonate inclusion occurs (followed by decomposition of the phase, Figure 1) and that this could be responsible for the increased unit cell sizes previously reported for $\mathrm{Ba}_{3} \mathrm{Nb}_{2} \mathrm{O}_{8}$.

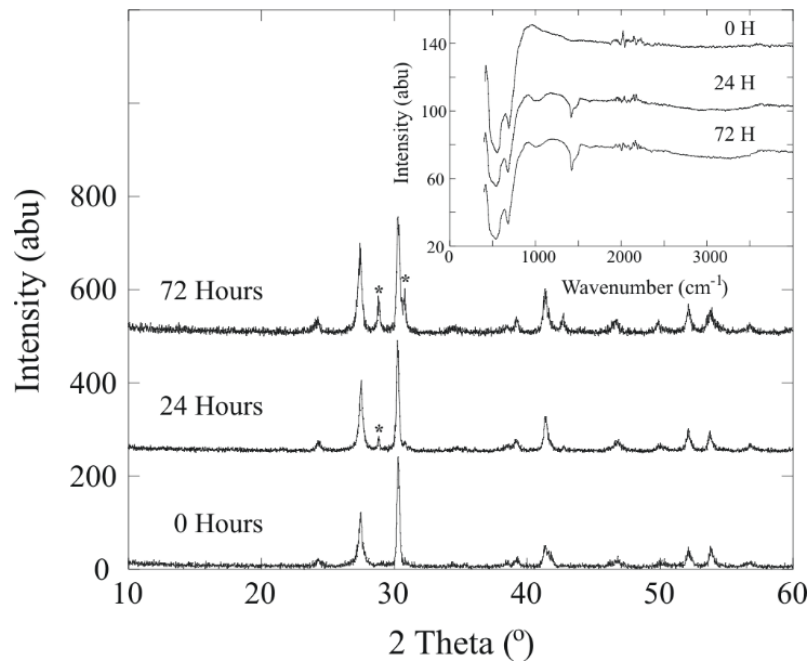

Figure 1 XRPD patterns of $\mathrm{Ba}_{3} \mathrm{Nb}_{2} \mathrm{O}_{8}$ showing the formation of the impurity phase, $\mathrm{Ba}_{5} \mathrm{Nb}_{4} \mathrm{O}_{15}$ (indicated by ${ }^{*}$ ), over a 72 hour period. Inset shows corresponding FTIR spectra with a peak attributed to carbonate inclusion at $\sim 1430 \mathrm{~cm}^{-1}$.

To further determine the structure of $\mathrm{Ba}_{3} \mathrm{Nb}_{2} \mathrm{O}_{8}$, high resolution neutron diffraction was carried out at room temperature and a series of models were tested via Rietveld refinement. A poor fit was obtained against the palmierite model containing $(h h c)_{3}$ stacking layers within the $R \overline{3} m$ space group (see Figure $S 1$ in supplementary data). A large degree of intensity mismatch between the calculated and observed peaks is evident, with some structural peaks not modelled at all (e.g. $h k l(2 \mathrm{O}-1),(2 \mathrm{o}-4))$ resulting in poor agreement indices of $\chi^{2}=483.7, R_{w p}=9.96 \%, R_{p}=10.03 \%$. Additional attempts allowing for the partial occupation of octahedra within the unit cell shown in Figure za were also made, with no improvement.

As a previous HREM study suggests that $\mathrm{Ba}_{3} \mathrm{Nb}_{2} \mathrm{O}_{8}$ crystallises in a primitive unit cell with a $9 \mathrm{H}$ structure ${ }^{21}$, refinements based on a series of $9 \mathrm{H}$ models were therefore attempted. Theoretically there are a total of six possible stacking sequences for the $9 \mathrm{H}$ type $^{32}$ and, rather than assuming the previous results, the neutron data were modelled by all potential variations.

In order to model the $\mathrm{Ba}$ and $\mathrm{Nb}$ sites as a first approximation, the six models were built up from the $\mathrm{BaO}_{3}$ stacking layers, as once these are fixed only one possible site remains for the B cation. Symmetry, to some extent, constrained the sequence used and each packing arrangement was "normalised" to start with $A B C$ in order to reflect the corresponding ch sequence described in Table 1 , along with the appropriate Zhdanov notation 33 . In addition, the B cation site was initially chosen to be octahedral, although cognisant of the fact that for the palmierite model each $\mathrm{BaO}_{3}$ $c$ layer in the $(c h h)_{3}$ packing sequence is replaced by $\mathrm{BaO}_{2}$, creating tetrahedral interstices. It was also recognised that vacancies must exist in the cation and anion sublattices, therefore this was tested within the models by refining the occupancy of each $\mathrm{Nb}$ and $\mathrm{O}$ site independently. The requirements to qualify as a successful model were low Rvalues, a good visual fit to the data, and realistic bondlengths.

All of the unit cell, atomic and profile parameters for each model were refined systematically to allow for direct comparison. An initial LeBail fit of the profiles ${ }^{34}$ for the two highest angle detector banks $\left(91.30^{\circ}\right.$ and $154.4^{\circ}$ ) was performed before refinement of the atomic positions. The resulting error indices, $R_{w p}, R_{p}$ and $\chi^{2}$, for each $9 H$ arrangement can be found in Table 1 and indicate that those with the highest number of adjacent $h$ layers (models 3 and 6) are the most promising. It should be noted that the long counting time used during the diffraction measurement has led to increased statistical precision and reduced $R_{\exp }$ values $\left(2.4 \times 10^{-6}-5.4 \times 10^{-7}\right.$ for Models $1-6$ and $2.5 \times 10^{-5}$ for Model 7), increasing the $R_{w p}$ : $R_{\exp }$ ratio; resulting in overinflated $\chi^{2}$ values.

In hexagonal unit cells with close packed $\mathrm{AO}_{\mathrm{x}}$ layers, cation vacancies tend to occur between adjacent $h h$ layers in 
order to stabilise the structure 35 (instead of between the cubic alternatives), so this is to be expected when considering the $\mathrm{Nb}$ vacancies in $\mathrm{Ba}_{3} \mathrm{Nb}_{2} \mathrm{O}_{8}$ The four remaining models (models 1, 2, 4 and

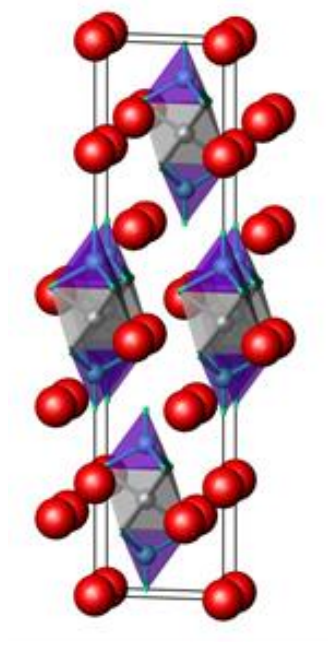

a

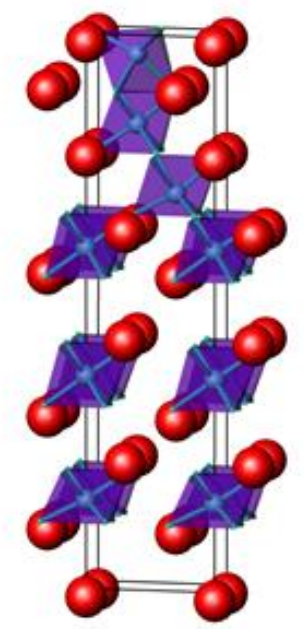

b

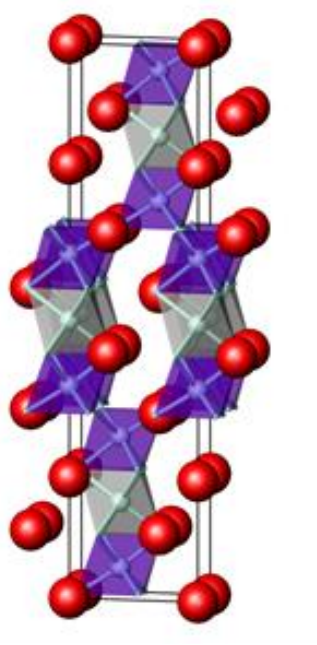

C

Figure 2 Crystal structures of a) the palmierite $\mathrm{A}_{3} \mathrm{~B}_{2} \mathrm{O}_{8}$, b) $\mathrm{Ba}_{3} \mathrm{Nb}_{2} \mathrm{O}_{8}$ c) ${ }_{9} \mathrm{R}$ perovskite $\mathrm{ABO}_{3}$. The grey polyhedra in palmierite indicate the empty octahedral sites. The cation deficient $9 \mathrm{R}$ structure (e.g. $\mathrm{Ba}_{3} \mathrm{Re}_{2} \mathrm{O}_{9}$ ) is similar to that of $\mathrm{ABO}_{3}$ but the grey octahedral sites are vacant.

Table 1: ABC packing layers, corresponding ch sequence and Zhdanov notation ${ }^{35}$ for each $9 \mathrm{H}$ unit cell model tested. The resulting $R_{p}$ and $w R_{p}$ are also given, alongside evidence of reasonable bond lengths.

\begin{tabular}{|c|c|c|c|c|c|c|c|c|}
\hline Model & $\begin{array}{l}\text { Space } \\
\text { Group }\end{array}$ & $\begin{array}{l}\text { Packing } \\
\text { layers }\end{array}$ & $\begin{array}{l}\text { Packing } \\
\text { type }\end{array}$ & $\begin{array}{l}\text { Zhdanov } \\
\text { notation }\end{array}$ & $\begin{array}{c}\text { Rp } \\
(\%)\end{array}$ & $\begin{array}{l}\text { Rwp } \\
(\%)\end{array}$ & $\chi^{2^{*}}$ & $\begin{array}{l}\text { Reasona- } \\
\text { ble bond } \\
\text { lengths? }\end{array}$ \\
\hline $\mathbf{1}$ & $\mathrm{P} \overline{3} \mathrm{~m} ı$ & АВCABACBC & cccchcche & $(6)(3)$ & 9.06 & 9.62 & 448.6 & No \\
\hline 2 & $\mathrm{P} \overline{3} \mathrm{~m} ı$ & АВСАСВСАВ & hcchchcch & $(2)_{3}(1)_{3}$ & 5.59 & 5.60 & 151.9 & No \\
\hline 3 & $\mathrm{P} \overline{3} \mathrm{~m} ı$ & АВСВСВСВС & cchhhhhhc & (4)11(1)11 & 4.25 & 4.50 & $97 \cdot 9$ & Some \\
\hline 4 & $\mathrm{P}_{3 \mathrm{~m} 1}$ & АВСАСВСВС & ccchchhhc & 5211 & 5.38 & $7 \cdot 37$ & 149.6 & No \\
\hline 5 & $\mathrm{P}_{3} \mathrm{m1}$ & АВСВАВСВС & cchchchhe & 4211 & 7.23 & 10.16 & 433.9 & No \\
\hline 6 & $\mathrm{P}_{3 \mathrm{~m} 1}$ & ABCACABAB & hcchhchhh & 31211 & 4.95 & 5.41 & 141.2 & Most \\
\hline 7 & $P_{3 m 1}$ & АВСВСВСАВ & hchhhhcch & 31211 & 2.49 & 2.54 & 31.82 & Yes \\
\hline
\end{tabular}

*Values of $\chi^{2}$ are inflated due to long counting times resulting in low $\mathrm{R}_{\exp }$ values of $2.4 \times 10^{-6}-5.4 \times 10^{-7}$ for Models $1-6$ and $2.5 \times$ $10^{-5}$ for Model 7 .

5, Table 1) were discarded as they displayed structural deficiencies, with unsatisfactory fits and/or erroneous thermal displacement parameters, including exceptionally small bond lengths in each of the 9 layers (e.g. Nb-O 1.02 $\AA$, $1.50 \AA$ ). Bond lengths of this size indicate an unsuitable unit cell, as the average bond length for $\mathrm{Nb}(\mathrm{V})$ octahedrally coordinated to oxygen is $2.04 \AA^{36}$ and the values obtained in models 1, 2, 4 and 5 fall largely outwith the expected range.

The refinement results for models 3 (ccchhhhhh $-\chi^{2}=$ 97.9, $w R p=4.50 \%, R p=4.25 \%$ and 6 (cchhchhhh $-\chi^{2}=$ 141.2, $w R p=5.41 \%, R p=4.95 \%$ ) are displayed in Figure S1 
(supplementary data); both show a similar quality of fit. However, some layers within the structures contained unrealistically small bond lengths along with large, negative displacement parameters on various sites (these layers are shaded white in Table $S_{1}$ in the supplementary data). As a result, a hybrid model was developed by extracting the realistic layers from both structures (shaded grey in Table $\mathrm{S} 1$ ), and re-assembling them to form a new model 7 (Table 2). In fact, this resulted in an alternative version of Model 6 with the origin shifted, suggesting that either the original model had resulted in a false minimum, or that a symmetry constraint had not been anticipated. The shift is 6 layers in, shown if $A B C A C A B A B$ is rewritten as $B C A B A B C B C$ and thus giving $\mathrm{ABCBCBCAB}$.
Model 7 (hchhhhcch) was tested according to the same protocol as the previous examples, giving improved initial agreement factors and a better visual fit to the collected data. The vacant niobium sites were determined by allowing the fractional occupancies to refine without constraints for all 9 potential $\mathrm{Nb}$ sites. Three of these positions $(2 \times 1 \mathrm{a}$ : $(\mathrm{o}, \mathrm{o}, \mathrm{z})$ and $\mathrm{l} \times \mathrm{lb}:(1 / 3,2 / 3, \mathrm{z})$ had very low or negative fractional occupancies and were therefore proposed as the vacant sites, giving the correct $\mathrm{Nb}$ stoichiometry expected for the $\mathrm{Ba}_{3} \mathrm{Nb}_{2} \mathrm{O}_{8}$ phase.

Table 2 Structural Parameters for $\mathrm{Ba}_{3} \mathrm{Nb}_{2} \mathrm{O}_{8}$ obtained from the Rietveld refinement of neutron diffraction data using model 7 .

\begin{tabular}{|c|c|c|c|c|c|c|}
\hline Atom & Wyk & $\mathrm{x} / \mathrm{a}$ & $y / b$ & $\mathrm{z} / \mathrm{c}$ & Occ. & $\mathrm{U}_{\text {iso }} / \AA^{3}$ \\
\hline $\mathrm{Ba}(1)$ & 1a & o & o & $-0.0366(11)$ & 1.0 & $0.0092(6)$ \\
\hline $\mathrm{Ba}(2)$ & $1 \mathrm{c}$ & $2 / 3$ & $1 / 3$ & $0.0718(12)$ & 1.0 & $0.0092(6)$ \\
\hline $\mathrm{Ba}(3)$ & $\mathrm{lb}$ & $1 / 3$ & $2 / 3$ & $0.2097(13)$ & 1.0 & $0.0092(6)$ \\
\hline $\mathrm{Ba}(4)$ & $1 \mathrm{c}$ & $2 / 3$ & $1 / 3$ & $0.2837(11)$ & 1.0 & $0.0092(6)$ \\
\hline $\mathrm{Ba}(5)$ & $\mathrm{lb}$ & $1 / 3$ & $2 / 3$ & $0.4149(12)$ & 1.0 & $0.0092(6)$ \\
\hline $\mathrm{Ba}(6)$ & $1 \mathrm{C}$ & $2 / 3$ & $1 / 3$ & $0.5330(13)$ & 1.0 & $0.0092(6)$ \\
\hline $\mathrm{Ba}(7)$ & $\mathrm{lb}$ & $1 / 3$ & $2 / 3$ & $0.6334(12)$ & 1.0 & $0.0092(6)$ \\
\hline $\mathrm{Ba}(8)$ & 1a & o & o & $0.7590(12)$ & 1.0 & $0.0092(6)$ \\
\hline $\mathrm{Ba}(9)$ & $1 \mathrm{c}$ & $2 / 3$ & $1 / 3$ & $0.8711(15)$ & 1.0 & $0.0092(6)$ \\
\hline $\mathrm{Nb}(1)$ & 1a & o & o & $0.1481(9)$ & 1.0 & $0.0140(8)$ \\
\hline $\mathrm{Nb}(2)$ & 1a & o & o & $0.3714(14)$ & 1.0 & $0.0140(8)$ \\
\hline $\mathrm{Nb}(3)$ & 1a & o & o & $0.5960(10)$ & 1.0 & $0.0140(8)$ \\
\hline $\mathrm{Nb}(4)$ & $1 \mathrm{c}$ & $2 / 3$ & $1 / 3$ & $0.6789(7)$ & 1.0 & $0.0140(8)$ \\
\hline $\mathrm{Nb}(5)$ & $\mathrm{lb}$ & $1 / 3$ & $2 / 3$ & $0.8097(10)$ & 1.0 & $0.0140(8)$ \\
\hline $\mathrm{Nb}(6)$ & $\mathrm{lb}$ & $1 / 3$ & $2 / 3$ & $0.9381(7)$ & 1.0 & $0.0140(8)$ \\
\hline $\mathrm{O}(1)$ & $3 d$ & $0.4891(12)$ & $0.5109(12)$ & $-0.0229(8)$ & 1.0 & $0.0139(4)$ \\
\hline $\mathrm{O}(2)$ & $3 d$ & $0.1760(15)$ & $0.8240(15)$ & $0.0962(7)$ & 1.0 & $0.0139(4)$ \\
\hline $\mathrm{O}(3)$ & $3 d$ & $0.8377(14)$ & $0.1623(14)$ & $0.1925(5)$ & 1.0 & $0.0139(4)$ \\
\hline $\mathrm{O}(4)$ & $3 d$ & $0.1600(15)$ & $0.8400(15)$ & $0.3055(7)$ & 1.0 & $0.0139(4)$ \\
\hline $\mathrm{O}(5)$ & $3 d$ & $0.8389(18)$ & $0.1611(18)$ & $0.4193(11)$ & 0.7 & $0.0139(4)$ \\
\hline $\mathrm{O}(6)$ & $3 d$ & $0.1353(15)$ & $0.8647(15)$ & $0.5344(9)$ & 0.7 & $0.0139(4)$ \\
\hline $\mathrm{O}(7)$ & $3 d$ & $0.8350(13)$ & $0.1650(13)$ & $0.6515(6)$ & 1.0 & $0.0139(4)$ \\
\hline $\mathrm{O}(8)$ & $3 d$ & $0.5064(14)$ & $0.4936(14)$ & $0.7576(8)$ & 1.0 & $0.0139(4)$ \\
\hline $\mathrm{O}(9)$ & $3 d$ & $0.1671(20)$ & $0.8329(20)$ & $0.8576(9)$ & 0.6 & $0.0139(4)$ \\
\hline
\end{tabular}

As expected, for a hexagonal unit cell containing a metal with a high cation charge and small ionic radii, these vacant octahedra are found situated between adjacent $h$ layers in order to stabilise the structure. This is consistent with what has been observed, for example, in the homologous series of hexagonal perovskites $\mathrm{La}_{n} \mathrm{Ti}_{n-\delta} \mathrm{O}_{3 \mathrm{n}}$, whereby the structures are described as having intrinsic stacking faults with the interstitial (Ti) sites in these layers remaining vacant ${ }^{37}$. In contrast with the previous studies ${ }^{1,18-21}$, there was no evidence of tetrahedral $\mathrm{Nb}$ and all of the niobium were found to occupy $\mathrm{NbO}_{6}$ octahedra. In order to 
confirm this, the local cation environment was investigated further by solid state ${ }^{93} \mathrm{Nb} \mathrm{NMR}$, which is described below. Similarly, oxygen vacancies were determined by refining the fractional occupancies on all 9 positions. The majority of sites gave values close to 1 , but 3 gave significantly lower occupancies with two close to 0.7 and one lower, close to 0.6 (positions $\mathrm{O}_{5}, \mathrm{O}_{6}$ and $\mathrm{O}_{9}$ in Table 2). Similarly, oxygen vacancies were determined by refining the fractional occupancies on all 9 positions.

The majority of sites gave values close to 1 , but 3 gave significantly lower occupancies with two close to 0.7 and one lower, close to 0.6 (positions $\mathrm{O}_{5}, \mathrm{O}_{6}$ and $\mathrm{O}_{9}$ in Table 2). Assuming the nominal stoichiometry, the sites were thus fixed at these values. After vacancy determination, constraints were re-introduced for the isotropic displacement parameters in order for all atomic positions to refine together and converge to the final values given in Table 2 . An excellent Rietveld fit for this model is obtained as shown in Figure 3, along with the corresponding agreement indices ( $\left.\chi^{2}=31.82, R_{w p}=2.54 \%, R_{p}=2.49 \%\right)$. This newly derived model gives lower agreement factors and an improved visual fit to the data, compared to the other $9 \mathrm{H}$ alternatives. The crystal structure of $\mathrm{Ba}_{3} \mathrm{Nb}_{2} \mathrm{O}_{8}$ is displayed in Figure $2 b$, showing a disordered unit cell comprised of $\mathrm{BaO}_{12}$ poly-hedra and corner-sharing, face-sharing and isolated $\mathrm{NbO}_{6}$ octahedra with entire vacant sites situated between hexagonal layers. It is one of the few oxides known to contain isolated $\mathrm{MO}_{6}$ octahedra, as conventionally, hexagonal unit cells opt for a more inter-connected network of polyhedra in order to stabilise the lattice.

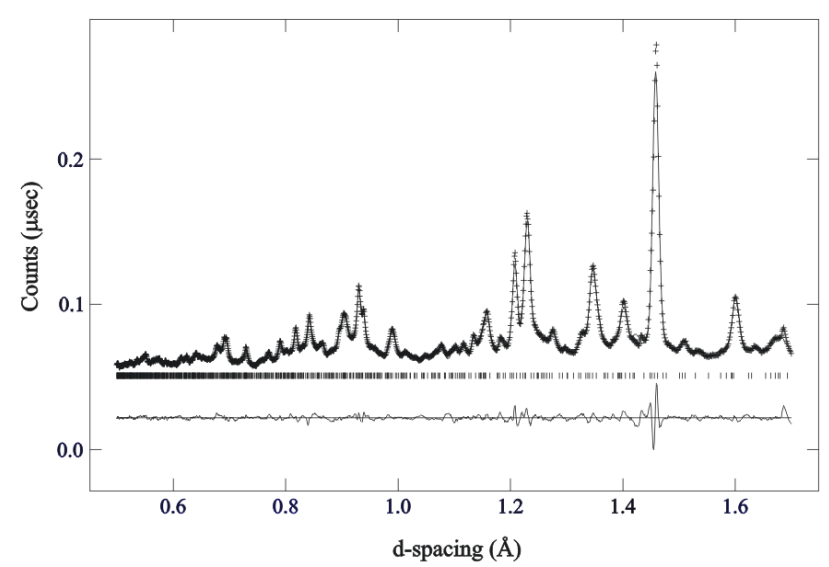

Figure 3 The Rietveld refinement fit of $\mathrm{Ba}_{3} \mathrm{Nb}_{2} \mathrm{O}_{8}$ in the space group $P_{3} m 1$ using model 7 ( $\mathrm{a}=5.90849$ (10), c = 20.9491(12) $\AA$ ). The fit shown is of the $154.4^{\circ}$ detector bank $\left(R_{w p}=0.0178, R_{p}=\right.$ o.0214). The figure shows the observed (crosses), calculated (line) and difference profile.

Table $3 \mathrm{Nb}-\mathrm{O}$ bond lengths for $\mathrm{NbO}_{6}$ octahedra in $\mathrm{Ba}_{3} \mathrm{Nb}_{2} \mathrm{O}_{8}$ according to model 7 .
$\mathrm{Nb}-\mathrm{O}$ Bond
Bond Length $(\AA ̊)$
$\mathrm{Nb}(1)-\mathrm{O}(2) \times 3$
2.103(19)

$$
\begin{array}{rl}
\mathrm{O}(3) \times 3 & 1.904(17) \\
\mathrm{Nb}(2)-\mathrm{O}(4) \times 3 & 2.14(2) \\
\mathrm{O}(5) \times 3 & 1.93(2) \\
\mathrm{Nb}(3)-\mathrm{O}(6) \times 3 & 1.89(2) \\
\mathrm{O}(7) \times 3 & 2.05(2) \\
\mathrm{Nb}(4)-\mathrm{O}(7) \times 3 & 1.815(14) \\
\mathrm{O}(8) \times 3 & 2.33(2) \\
\mathrm{Nb}(5)-\mathrm{O}(8) \times 3 & 2.08(2) \\
\mathrm{O}(9) \times 3 & 1.98(2) \\
\mathrm{Nb}(6)-\mathrm{O}(1) \times 3 & 1.792(15) \\
\mathrm{O}(9) \times 3 & 2.395(19)
\end{array}
$$

\section{Solid State ${ }^{93} \mathrm{Nb}$ NMR.}

The static ${ }^{33} \mathrm{Nb}$ NMR data acquired at 9.4 and $18.8 \mathrm{~T}$ from the $\mathrm{Ba}_{3} \mathrm{Nb}_{2} \mathrm{O}_{8}$ system is presented in Figure $4 \mathrm{a}$, and these spectra show that two featureless overlapping resonances of very different linewidth characterise the $\mathrm{Nb}(\mathrm{V})$ speciation at each $B_{0}$ field. The ratio of integrated intensities for these resonances is $\sim 2: 1$ with the broader, more dispersed component appearing more dominant. This characteristic is consistent with the structural parameters presented in Tables 2 and 3 which indicate that four of the six Nb positions ( $\mathrm{Nb}_{2}, \mathrm{Nb}_{3}, \mathrm{Nb}_{5}$ and $\mathrm{Nb6}$ ) are influenced by partial occupancies in the $\mathrm{O}_{5}, \mathrm{O}_{6}$ and $\mathrm{O}_{9}$ positions; the remaining $\mathrm{Nb} 1$ and $\mathrm{Nb}_{4}$ positions represent regular octahedral environments. The variable $B_{0}$ behaviour (i.e. centre-of-gravity shift $\left.\left(\delta_{\mathrm{cg}}\right)\right)$ of each resonance is graphically represented in Figure $4 \mathrm{~b}$ where the well-established field dependence of the second order quadrupole shift $\left(\delta_{\mathrm{Q}, \text { iso }}{ }^{(2)}(I, m)\right)$ component is exploited. This dependence can be written $\mathrm{as}^{38,39}$ :

$$
\delta_{\mathrm{cg}}=\delta_{\text {iso }}+\delta_{\mathrm{Q}, \text { iso }}^{(2)}(I, m)
$$

where

$$
\begin{aligned}
& \delta_{\mathrm{Q}, \text { iso }}^{(2)}(I, m)=\mathrm{A}[I(I+1)-9 m(m-1)-3]\left(1+\eta_{\mathrm{Q}^{2}} / 3\right) \\
& \text { with } \mathrm{A}=\left({ }_{3} C_{\mathrm{Q}^{2}} /\left(4 \mathrm{o} v_{\mathrm{o}}{ }^{2} I^{2}(2 I-1)^{2}\right)\right)
\end{aligned}
$$

If the variation in $\delta_{\mathrm{cg}}$, is plotted as a function of $1 / v_{0}{ }^{2}$, then by graphical methods the isotropic chemical shift $\left(\delta_{\text {iso }}\right)$ and the quadrupolar interaction constant $\left(P_{\mathrm{Q}}=C_{\mathrm{Q}} \sqrt{ }\left(1+\eta_{\mathrm{Q}^{2}} / 3\right)\right)$ can be estimated from the y intercept and slope of these data, respectively ${ }^{40,41}$. This analysis of the static ${ }^{93} \mathrm{Nb} \mathrm{NMR}$ data for the narrow resonance representing $\mathrm{Nb}$ environments that are unaffected by $\mathrm{O}$ partial occupancies is illustrated in Figure $4 \mathrm{~b}$ and symbolized by the squares ( $\mathbf{m})$; it provides a reliable estimate of the isotropic chemical shift $\left(\delta_{\text {iso }}=-928 \pm 5 \mathrm{ppm}\right)$ and quadrupolar interaction parameter $\left(P_{\mathrm{Q}}=10 \pm 2 \mathrm{MHz}\right)$ for these $\mathrm{Nb}$ positions in the $\mathrm{Ba}_{3} \mathrm{Nb}_{2} \mathrm{O}_{8}$ system. 


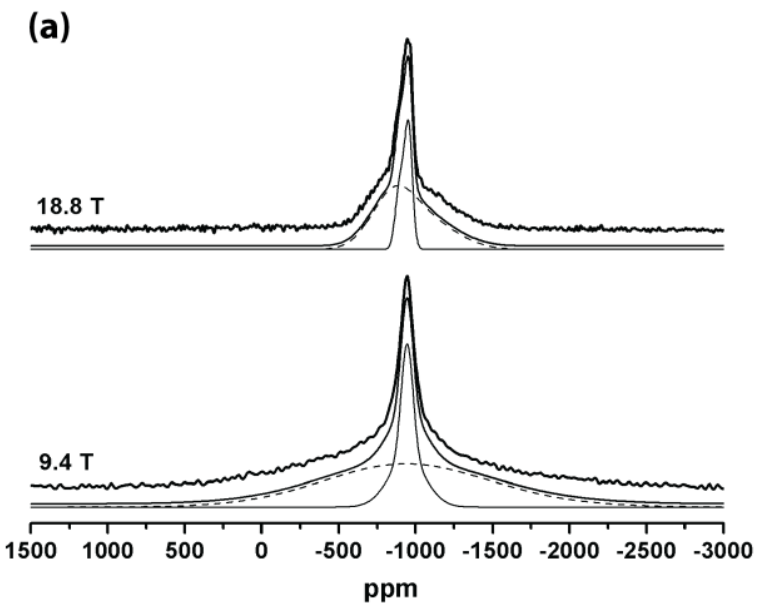

(b)

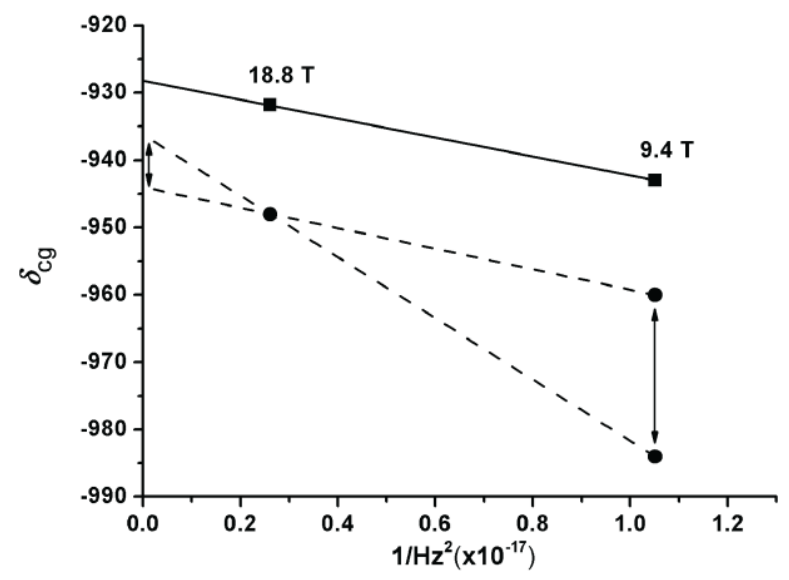

Figure 4 (a) Static $93 \mathrm{Nb} \mathrm{NMR}$ spectrum for $\mathrm{Ba}_{3} \mathrm{Nb}_{2} \mathrm{O}_{8}$ at $18.8 \mathrm{~T}$ and $9.4 \mathrm{~T}$ showing two overlapping resonances with differing linewidths. The thick line is the raw data, with the other lines showing the fit and the two resolved contributions with very different line widths. (b) Centre-of-gravity shift, $\delta_{\mathrm{cg}}$, as a function of $1 / v_{0}^{2}$ : squares ( $\square$ ) represent those environments unaffected by oxygen vacancies (sharper peak in (a)) whereas circles $(\bullet)$ represent those with broader peaks where vacancies affect the local environment, whilst remaining octahedral in nature.

Since the quadrupole asymmetry parameter $\left(\eta_{\mathrm{Q}}\right)$ is not independently elucidated from this analysis, this $P_{\mathrm{Q}}$ value is equivalent to a quadrupole coupling constant $\left(C_{\mathrm{Q}}\right)$ in the range of $\sim 7-10 \mathrm{MHz}$. Previous studies have demonstrated that small $C_{\mathrm{Q}}$ values of this magnitude and a $\delta_{\text {iso }}<\sim-900$ ppm is strong evidence of six-fold oxo-coordinated $\mathrm{Nb}(\mathrm{V})$ positions ${ }^{42}$. The broader ${ }^{93} \mathrm{Nb}$ resonance is much more difficult to characterise with reliable estimates of $\delta_{\text {iso }}$ and $P_{\mathrm{Q}}$, however some assertions can be made regarding the disordered framework it represents. The $18.8 \mathrm{~T}$ data is sufficiently defined to establish that $\delta_{\mathrm{cg}}$ is further upfield than the corresponding data for the narrow resonance; furthermore, the estimated range of probable $\delta_{\text {cg }}$ values from the 9.4 T data permits a range of $\delta_{\text {iso }}$ values of $\sim 944^{-}-937 \mathrm{ppm}$ to be ascertained, as indicated by the circular points $(\bullet)$ in
Figure $4 \mathrm{~b}$. This $\delta_{\text {iso }}$ range establishes that these $\mathrm{Nb}(\mathrm{V})$ positions represented by the broader component are also octahedral $\left(\mathrm{NbO}_{6}\right)$ in character, and the large difference (increase) in ${ }^{93} \mathrm{Nb}$ linewidth between the 18.8 and 9.4 $\mathrm{T}$ measurements indicates that these resonances are unambiguously quadrupole rather than chemical shift dispersion dominated.

\section{DISCUSSION}

Figure 2 shows the crystal structure of $\mathrm{Ba}_{3} \mathrm{Nb}_{2} \mathrm{O}_{8}$, alongside that of the palmierite $\mathrm{A}_{3} \mathrm{~B}_{2} \mathrm{O}_{8}$ and the ${ }_{9} \mathrm{R}$ hexagonal perovskite $\mathrm{ABO}_{3}$. The $9 \mathrm{R}$ polytype $(h h c)_{3}$ can accommodate ordered cationic vacancies within its structure, for example in $\mathrm{A}_{3} \mathrm{~B}_{2} \mathrm{O}_{9}$ compositions such as $\mathrm{Ba}_{3} \mathrm{Re}_{2} \mathrm{O}_{9}$. This deficiency is achieved by removal of the polyhedron lying in the centre of the 3 face-sharing octahedral block (shown in grey in Figure 2c), and from there the palmierite may be derived by the replacement of the cubic $\mathrm{BaO}_{3}$ layer in the (chh) sequence with $\mathrm{a} \mathrm{BaO}_{2}$ layer; hence the stacking sequence is essentially retained in palmierite. While the $9 \mathrm{R}$ structure is comprised of corner-sharing $\mathrm{BO}_{6}$ octahedra, the change in the cubic layer to transform to the palmierite phase results in the formation of isolated tetrahedra. These structures are somewhat interchangeable with $\mathrm{Ba}_{3} \mathrm{Nb}_{2} \mathrm{O}_{8}$, as a "reversal" of the layers can be seen. When considering the ${ }_{9} \mathrm{R} /$ palmierite with the $(c h h)_{3}=[c h h][c h h][c h h]$ packing sequence, $\mathrm{Ba}_{3} \mathrm{Nb}_{2} \mathrm{O}_{8}$ can be re-written as [chh][hhc][chh]; with the central sequence inverted. Therefore the structure of $\mathrm{Ba}_{3} \mathrm{Nb}_{2} \mathrm{O}_{8}$ proposed here retains some similarities to that of the $9 \mathrm{R}$ polytype and palmierite. At the centre of all three unit cells lies an octahedral site which can either be occupied or vacant in the $9 \mathrm{R}$, but is empty for $\mathrm{Ba}_{3} \mathrm{Nb}_{2} \mathrm{O}_{8}$ and also the palmierite. Overall, the $9 \mathrm{H}$ structure of $\mathrm{Ba}_{3} \mathrm{Nb}_{2} \mathrm{O}_{8}$ contains 3 distinct octahedral environments (with isolated, corner-sharing octahedra as well as face-sharing dimers) and is a more disordered system than either the palmierite or $9 \mathrm{R}$ structures.

The oxygen atoms in $\mathrm{Ba}_{3} \mathrm{Nb}_{2} \mathrm{O}_{8}$ occupy $3 \mathrm{~d}$ positions, with vacancies formed within the hexagonal $(h)$ layers of the structure (Table 2). Two of these partially occupied sites (O5 and O6) are concentrated in the central block of the unit cell where a vacant layer of octahedral cation sites are found (Figure $2 \mathrm{~b}$ ). The other site ( $\mathrm{O}_{9}$ ) occurs in the upper part of the unit cell within the common face of the facesharing dimers; this has also been noted in some $\mathrm{BaMO}_{3-\delta}$ oxygen-deficient $6 \mathrm{H}$ perovskites such as $\mathrm{Ba}(\mathrm{Ti}, \mathrm{Fe}) \mathrm{O}_{3-8} \delta^{43} \mathrm{Ba}-$ $\mathrm{TiO}_{3-\delta},{ }^{44}$ and $\mathrm{BaTi}_{1-y} \mathrm{Co}_{\mathrm{y}} \mathrm{O}_{3-8}{ }^{45}$ Indeed, it was noted in a study of $6 \mathrm{H}-\mathrm{BaFeO}_{2.79}$ that oxygen vacancies preferentially form in the hexagonal layers rather than the cubic alternatives ${ }^{46}$, as seen in the present work.

In accordance with early studies on perovskite stacking by Katz and Ward ${ }^{35}$, the structure accommodates the unfavourable long sequence of hexagonal packed layers (hhhh) with B-site vacancies situated between alternate $h$ layers. These vacancies are located towards the center and lower region of the unit cell where, rather than a long chain 
of face-sharing octahedra in this area (which would be unstable due to the high electrostatic repulsion from neighboring $\mathrm{Nb}^{5+}$ cations), we observe instead isolated $\mathrm{NbO}_{6}$ units. This arrangement acts to reduce strain in this section of the unit cell, which is demonstrated by the more 'ideal' octahedron when compared to those contained in the rest of the unit cell. One occupied $(h h)$ unit is retained in the top part of the cell, within the (chh) sequence. This is the section of the structure exhibiting the most strain, showing the upper octahedron of the face sharing dimer $(\mathrm{Nb}(6)(\mathrm{lb})$ site) to be the most distorted within the structure. This is demonstrated by the $\mathrm{Nb}-\mathrm{O}$ bond-lengths given in Table 3 , where the shortest and longest $\mathrm{Nb}(6)-\mathrm{O}$ bonds are 1.792(15) and 2.395(19) $\AA$ for $\mathrm{O}_{1}$ and $\mathrm{O}_{9}$ respectively. The $\mathrm{Ba}-\mathrm{O}$ bond lengths and $\mathrm{O}-\mathrm{Nb}-\mathrm{O}$ bond angles are shown in Tables $\mathrm{S}_{2}$ and $\mathrm{S}_{3}$ respectively (Supplementary data). The distorted angles show great departure from those expected of an ideal octahedron (e.g. $\mathrm{O}(1)-\mathrm{Nb}(6)-\mathrm{O}(1)=100.8(9)^{\circ}$, $\mathrm{O}(9)$ $\left.\mathrm{Nb}(6)-\mathrm{O}(9)=75.9(8)^{\circ}\right)$ shown in Table 3 within the supplementary data. This strain is likely eased, to some extent, by the oxygen vacancies within the face-sharing layer on the $\mathrm{O}(9)$ site. This highly distorted dimer is connected to a corner-sharing octahedron, $(\mathrm{Nb}(4)$ (1c), which is situated between $c c$ layers and contains bond angles which also depart noticeably from the ideal $90^{\circ}$ value $((\mathrm{O}(7)-\mathrm{Nb}(4)-\mathrm{O}(7)=$ $\left.110.5(5)^{\circ}, \mathrm{O}(8)-\mathrm{Nb}(4)-\mathrm{O}(8)=75.3(6)^{\circ}\right)$. This region is the most crowded, with the $\mathrm{Nb}(4)$ octahedron surrounded by 3 neighbouring $\mathrm{Nb}^{5+}$ complexes. In general, the functionality of a material is strongly dependent on its structure as distorted cation environments have been shown to be responsible for the substantial oxide ion conductivity in $\mathrm{Ba}_{3} \mathrm{MoNbO}_{8.5}$ and the dielectric properties of $\mathrm{Ba}_{5} \mathrm{Nb}_{4} \mathrm{O}_{15}{ }^{10}$, 23,47. Similar to $\mathrm{Ba}_{3} \mathrm{Nb}_{2} \mathrm{O}_{8}$, they are both hexagonal perovskite derivatives with cation vacancies, although in comparison $\mathrm{Ba}_{3} \mathrm{Nb}_{2} \mathrm{O}_{8}$ displays a much higher degree of cationic distortion. The octahedral $\mathrm{Mo} / \mathrm{Nb}$ environments within the polyhedra of $\mathrm{Ba}_{3} \mathrm{MoNbO}_{8.5}$ possess angles between $95.21^{\circ}$ and $84.38^{\circ}$, with a range of bond lengths from 2.12 and $2.21 \AA$. One of the oxygen positions, $\mathrm{O}(3)$, is disordered onto the $36 i$ positions as a result of the short distance between $\mathrm{Ba}(2)$ and $\mathrm{Mo}(1) / \mathrm{Nb}(1)$, so that the disorder stabilises the structure resulting in longer and more realistic $\mathrm{Ba}(2)-\mathrm{O}(3)$ and $\left.\mathrm{Mo}(1) / \mathrm{Nb}(1)-\mathrm{O}_{3}\right)$ bond lengths. The distorted cation positions display large anisotropic thermal motion values $\left(U_{11}=U_{22}=0.0049(2) \AA^{2} ; U_{33}=0.0498(9) \AA^{2}\right.$; $\left.U_{12}=0.0025(1) \AA^{2}\right)$, most likely resulting from the fluctuating coordination environment of the $\mathrm{Mo} / \mathrm{Nb}$ atoms. In the ${ }_{5} \mathrm{H}$ perovskite, $\mathrm{Ba}_{5} \mathrm{Nb}_{4} \mathrm{O}_{15}, \mathrm{Nb}^{5+}$ is described as too small to form regular $\mathrm{NbO}_{6}$ octahedra ${ }^{47,48}$. Selected octahedra were noted to have large differences in bond lengths (1.871 and $2.266 \mathrm{~A}^{\circ}$ for $\mathrm{Nb}(2)-\mathrm{O}(3)$ and $\mathrm{Nb}(2)-\mathrm{O}(2)$, respectively) and bond angles that show a great departure from that of an ideal octahedron $\left(\mathrm{O}(2)-\mathrm{Nb}(2)-\mathrm{O}(2)=82.74^{\circ}\right)$. Therefore, considering the highly distorted environments described here for $\mathrm{Ba}_{3} \mathrm{Nb}_{2} \mathrm{O}_{8}$, investigation into the dielectric properties of the material are warranted given the distorted $\mathrm{NbO}_{6}$ environments in $\mathrm{Ba}_{5} \mathrm{Nb}_{4} \mathrm{O}_{15}$. The distortion of $\mathrm{NbO}_{6}$ octahedral units is also one of the factors affecting the bandgap energy of layered perovskite materials. As the bond angle O-Nb-O moves away from the ideal values of $90^{\circ} / 180^{\circ}$, the band gap becomes wider and the excited energy state is localized ${ }^{49}$. This makes distorted niobate and tantalate materials prime candidates for photocatalytic applications. $\mathrm{Ba}_{3} \mathrm{Nb}_{2} \mathrm{O}_{8}$ could be an interesting material to investigate as it possesses a highly distorted unit cell coupled with a thin perovskite layer, which is an important feature when considering wide band gap materials because as the thickness of the layer decreases, the two dimensionality of the crystal structure becomes high.

The structural model proposed here for $\mathrm{Ba}_{3} \mathrm{Nb}_{2} \mathrm{O}_{8}$ describes a unit cell containing fully octahedral niobium sites, with this environment supported by the results of the ${ }^{93} \mathrm{Nb}$ NMR study. This differs from previous accounts of the structure which present cationic lattices with between 50 $92.5 \%$ of the niobium in tetrahedral coordination ${ }^{1,18-21}$. Two types of six-fold oxo-coordinated $\mathrm{Nb}(\mathrm{V})$ positions were detected which exhibit NMR parameters that are very distinct from the corresponding four-fold oxo-coordinated species. Previous studies have demonstrated that $\mathrm{NbO}_{4}$ moieties are characterised by very large $C_{\mathrm{Q}}$ values of $>8 \mathrm{o} \mathrm{MHz}$ and downfield shifted $\delta_{\text {iso }}$ values of $>-860 \mathrm{ppm}^{39}$. From the ${ }^{93} \mathrm{Nb}$ static NMR evidence presented here, $\mathrm{NbO}_{4}$ structural moieties are clearly absent from the $\mathrm{Ba}_{3} \mathrm{Nb}_{2} \mathrm{O}_{8}$ structure (Figure $2 \mathrm{~b}$ ), thus corroborating the neutron diffraction refinement results which together establish a clear demarcation from the tetrahedral palmierite structure shown in Figure 2a). The absence of $\mathrm{NbO}_{4}$ polyhedra in $\mathrm{Ba}_{3} \mathrm{Nb}_{2} \mathrm{O}_{8}$ also contradicts the findings of previous HREM and Raman spectroscopy studies, where a 1:1 ratio of octahedral to tetrahedral sites was anticipated ${ }^{20,21}$.

The space group and atomic model resolved from this neutron diffraction study is in stark contrast with those previously reported for $\mathrm{Ba}_{3} \mathrm{Nb}_{2} \mathrm{O}_{8}$, as several XRD studies indicate that the material crystallises in the $R \overline{3} m$ space group with $(h h c)_{3}$ layers ${ }^{1,18,19}$. The study by Kemmler-Sack et al. ${ }^{19}$ describes a palmierite unit cell where $7.5 \%$ of the $\mathrm{Nb}$ occupy the typically vacant octahedra shown in grey in Figure 2a). A subsequent single crystal XRD study suggested that $\mathrm{Ba}_{3} \mathrm{Nb}_{2} \mathrm{O}_{8}$ crystallises in the standard palmierite unit cell where only isolated tetrahedra exist ${ }^{1}$. There are a number of potential reasons for these structural discrepancies; firstly there is the comparison between $\mathrm{X}$-ray and neutron data. The majority of X-ray scattering in $\mathrm{Ba}_{3} \mathrm{Nb}_{2} \mathrm{O}_{8}$ is due to the higher scattering of the barium and niobium ions which consequently dominate the diffraction pattern obtained, making analysis of the anionic lattice incomplete due to the relatively poor scattering intensity of oxygen. It is important to note here that our XRD data could also be satisfactorily refined using the palmierite model (with and without partially occupied octahedra) and that discrepancies only arose once analysis of the neutron diffraction data was attempted and the scattering of oxygen became relevant. Rietveld refinement of neutron diffraction data is 
more appropriate for the structure determination of complex oxides such as $\mathrm{Ba}_{3} \mathrm{Nb}_{2} \mathrm{O}_{8}$ because it allows for increased precision when determining the position of lighter elements, such as oxygen. Poorly resolved oxygen sites will lead to inaccurate cation coordination environments and vacancy distributions within the unit cell. The unit cell parameters of the phases reported in previous XRD studies are noticeably larger than those extracted from our preliminary XRD data and neutron diffraction refinement results. In the previous studies, no measures are described to avoid decomposition of the $\mathrm{Ba}_{3} \mathrm{Nb}_{2} \mathrm{O}_{8}$ phase although, in the single crystal study ${ }^{1}$, Vanderah et al. proposed that the instability of $\mathrm{Ba}_{3} \mathrm{Nb}_{2} \mathrm{O}_{8}$ could be a result of the unusual tetrahedral co-ordination of $\mathrm{Nb}^{5+}$. Our characterisation of powder samples via X-ray and neutron diffraction, ${ }^{93} \mathrm{Nb} \mathrm{NMR}$ and FTIR spectroscopy reveal $\mathrm{Nb}^{5+}$ to be in octahedral coordination and that the decomposition of the phase is instead due to the inclusion of carbonate (Figure 1 (inset)). It is also notable that the unit cell parameters from the single crystal study ${ }^{1}(a=6.0477(13), c=21.289(5) \AA)$ are significantly larger than those reported here $(a=5.90849(10), c=$ 20.9491(12) $\AA$ ). There is also precedent in that there are many reported perovskite-based materials that have an affinity for carbonate inclusion due to their high content of alkali-earth metal cations, one such example being $\mathrm{Ba}_{3} \mathrm{CO}_{2} \mathrm{O}_{6}\left(\mathrm{CO}_{3}\right)_{0.60^{50}}$.

The storage of bulk samples of $\mathrm{Ba}_{3} \mathrm{Nb}_{2} \mathrm{O}_{8}$ under vacuum and in $\mathrm{N}_{2}$ prevented the formation of a secondary phase suggesting that atmospheric $\mathrm{CO}_{2}$ is the primary cause of decomposition. There are many reported perovskite-based materials with an affinity for carbonate inclusion due to their high content of alkali-earth metal cations. It has been reported that the up-take of water and carbonate upon cooling in the compound $\mathrm{Ba}_{4} \mathrm{Nb}_{2} \mathrm{O}_{9}$, where small amounts of carbonate replace oxygen and $\left(\mathrm{CO}_{3}\right)^{2-}$ ions are found to occupy the vacant cation sites ${ }^{7}$. Therefore, the larger unit cell parameters described for $\mathrm{Ba}_{3} \mathrm{Nb}_{2} \mathrm{O}_{8}$ within the previous work might suggest the inclusion of interstitial ions such as $\left(\mathrm{CO}_{3}\right)^{2-}$. It is likely that, initially, carbonate inclusion occurs on a vacant cation site (similar to $\mathrm{Ba}_{4} \mathrm{Nb}_{2} \mathrm{O}_{9}$ ), followed by decomposition of the phase within a 24 hour time period due to the instability of the highly distorted octahedral environments within $\mathrm{Ba}_{3} \mathrm{Nb}_{2} \mathrm{O}_{8}$. The vacant sites likely occupied by atmospheric $\left(\mathrm{CO}_{3}\right)^{2-}$ are situated between adjacent hexagonal layers $(h h)$; we have described previously that vacancies on these sites are integral to the stability of the structure and partial occupation could result in a timely collapse of the structure into the more stable $\mathrm{Ba}_{5} \mathrm{Nb}_{4} \mathrm{O}_{15}$ phase.

The $9 \mathrm{H}$ model we propose does bear some resemblance to the structures discussed by Garcia-Gonzalez et al. in their HREM study ${ }^{21}$. However, it was not previously possible to determine the definitive $c h$ layer sequence within the $9 \mathrm{H}$ unit cell, or to extract accurate atomic coordinates or vacancy distributions from modelling of the HREM images. Two possible models were proposed for the structure of $\mathrm{Ba}_{3} \mathrm{Nb}_{2} \mathrm{O}_{8}$ (models 3 and 6 in Table 1 ) comprised of one
$\mathrm{BaO}$, one $\mathrm{BaO}_{2}$ and seven $\mathrm{BaO}_{3}$ layers. The XRD refinements of both models were deemed unsuccessful (resulting in large $\mathrm{R}$ factors) and the distribution of cationic vacancies could not be statistically determined. It was concluded that neither of the two models used to analyse the experimental images accurately describes the structure of $\mathrm{Ba}_{3} \mathrm{Nb}_{2} \mathrm{O}_{8}$ and that an intermediate structure between the two models is likely. It was also suggested that a 1:1 ratio of octahedrally and tetrahedrally coordinated $\mathrm{Nb}$ atoms is present in $\mathrm{Ba}_{3} \mathrm{Nb}_{2} \mathrm{O}_{8}$. The existence of tetrahedral $\mathrm{Nb}$ was supported by a Raman spectroscopy study on cation-deficient barium niobate phases ${ }^{20}$. Bands appearing near 300 and $800 \mathrm{~cm}^{-1}$ were attributed to tetrahedral $\mathrm{Nb}$ units. However, Raman spectroscopy studies of the fully octahedral niobium environment within $(\mathrm{Ba}, \mathrm{Sr})_{5} \mathrm{Nb}_{4} \mathrm{O}_{15}$ also produced strong bands in these regions ${ }^{47,51}$, and could therefore be a result of symmetric stretching modes of the $\mathrm{NbO}_{6}$ octahedra.

Refinement using neutron diffraction data has now allowed the structure of $\mathrm{Ba}_{3} \mathrm{Nb}_{2} \mathrm{O}_{8}$ to be fully elucidated. The advantages of using neutron diffraction over HREM to characterise these complex materials has also been highlighted during the recent report of $\mathrm{Ba}_{3} \mathrm{MoNbO}_{8.5}$. Electron microscopy studies originally described an ordered structure comprising intertwined regions of $\mathrm{Mo} / \mathrm{NbO}_{6}$ octahedra and $\mathrm{Mo} / \mathrm{NbO}_{4}$ tetrahedra ${ }^{52}$, but neutron diffraction results suggest that $\mathrm{Ba}_{3} \mathrm{MoNbO}_{8.5}$ is a highly disordered and more complicated hybrid structure. For fuller understanding of structure/property relationships this level of detail is necessary; for example, resistivity measurements on $\mathrm{Ba}_{3} \mathrm{MoNbO}_{8.5}$ showed that the disordered structure has a predisposition for oxide ion conduction, which may have been overlooked in a simplified structural model. Whilst our results describe a structure tentatively derived from one of the models originally predicted by the HREM study, it disagrees with the previous topological predictions of an ordered anionic lattice, along with the fractional occupation of $\mathrm{Nb}$ octahedra and the presence of $\mathrm{NbO}_{4}$ units. The structure of $\mathrm{Ba}_{3} \mathrm{Nb}_{2} \mathrm{O}_{8}$ is distinct from both the palmierite and all previously reported 9-layer perovskite derivatives, with a highly distorted niobium environment making it a promising candidate for future dielectric and photocatalytic studies. Recent developments prove that the thorough characterisation of new hexagonal structures may hold the key to the discovery of new families of fast ionic conductors.

\section{CONCLUSIONS}

This investigation of the average and local structure of $\mathrm{Ba}_{3} \mathrm{Nb}_{2} \mathrm{O}_{8}$ confirms that the phase is derived from a $9 \mathrm{H}$ perovskite unit cell with layers arranged in a (hchhhhcch) sequence. For the first time, the location and distribution of anionic and cationic vacancies has been determined. Combined neutron and solid state NMR studies reveal niobium to occupy 6 distorted octahedral sites with 3 complete va- 
cancies situated between consecutive $h h$ close-packed layers, the location of which are required to stabilise the 9 layered structure. Although this coordination environment and structural model for $\mathrm{Ba}_{3} \mathrm{Nb}_{2} \mathrm{O}_{8}$ is unprecedented in the literature, the advantages of neutron diffraction over the techniques described are clearly apparent and also support the fact that $\mathrm{Nb}^{5}$ is rarely found in tetrahedral environments due to its large size ${ }^{53}$. The anionic lattice is shown to be disordered, with the fractional occupancy of 3 sites distributed within hexagonal layers. This structure is thus distinct from all known reported 9-layer perovskite derived structures, including the palmierite. Carbonate inclusion via the atmosphere is thought to be responsible for the decomposition of the phase into $\mathrm{Ba}_{5} \mathrm{Nb}_{4} \mathrm{O}_{15}$.

\section{AUTHOR INFORMATION}

\section{Corresponding Author}

*E-mail: j.skakle@abdn.ac.uk

\section{Author Contributions}

The manuscript was written through contributions of all authors. All authors have given approval to the final version of the manuscript.

\section{Notes}

The authors declare no competing financial interests.

\section{ACKNOWLEDGMENT}

JMSS, ACM and EJW acknowledge support from the University of Aberdeen for funding and RCUK/ISIS for neutron time.

JVH acknowledges the continued funding of the Solid State NMR Facility and other instrumentation at Warwick used in this research which was facilitated by EPSRC, the University of Warwick and partial funding through Birmingham Science City Advanced Materials Projects 1 and 2, which in turn was supported by Advantage West Midlands (AWM) and the European Regional Development Fund (ERDF).

\section{ASSOCIATED CONTENT}

Supporting Information. Supplementary information of the derivation of Model 7, an extended list of bond lengths, and figures of the Rietveld fits for 3 models are provided.

\section{ABBREVIATIONS}

NMR, Nuclear Magnetic Resonance; FTIR, Fourier Transform InfraRed Spectroscopy; XRD, X-ray Diffraction

\section{REFERENCES}

(1) Vanderah, T.A.; Collins, T.R.; Wong-Ng, W.; Roth, R.S.; Farber, $\mathrm{L}$. Phase equilibria and crystal chemistry in the $\mathrm{BaO}-\mathrm{Al}_{2} \mathrm{O}_{3}-$ $\mathrm{Nb}_{2} \mathrm{O}_{5}$ and $\mathrm{BaO}-\mathrm{Nb}_{2} \mathrm{O}_{5}$ systems. J. Alloys Comp. 20o2, 346, 116-128. (2) Leshchenko, P.P.; Lykova, L. N.; Kovba, L. M.; Stefanovich, S. Y.; Chechkin, V. V. Phase transitions in $\mathrm{Ba}_{4} \mathrm{Nb}_{2} \mathrm{O}_{9}$. Inorg. Mater. 1985, 21(2), 227-230.

(3) Bezjak, J.; Jaňcar, B.; Recnik, A.; Suvorov. D. The synthesis and polymorphic phase transitions of $\mathrm{Ba}_{4} \mathrm{Nb}_{2} \mathrm{O}_{9}$ ceramics. J. Eur. Ceram. Soc, 2009, 28, 2771-2776.

(4) Ling, C.D.; Avdeev, M.; Kutteh, R.; Kharton, V.V.; Yaremchenko, A. A.; Fialkova, S.; Sharma, N.; Macquart, R. B.; Hoelzel, M.; Gutmann, M. Structures, phase transitions, hydration, and ionic conductivity of $\mathrm{Ba}_{4} \mathrm{Nb}_{2} \mathrm{O}_{9}$. Chem. Mater. 2009, 21, 38533864 .

(5) Zou, Z.; Arakawa, H. Direct water splitting into $\mathrm{H}_{2}$ and $\mathrm{O}_{2}$ under visible light irradiation with a new series of mixed oxide semiconductor photocatalysts. J. Photochem. Photobiol. A: Chem. 2003, 158, 145-162.

(6) Kato, H.; Kudo, A. Photocatalytic water splitting into $\mathrm{H}_{2}$ and $\mathrm{O}_{2}$ over various tantalate photocatalysts. Catal. Today 2003, 78, 561-569.

(7) Galasso, F.; Katz, L. Preparation and structure of $\mathrm{Ba}_{5} \mathrm{Ta}_{4} \mathrm{O}_{15}$ and related compounds. Acta Cryst. 1961, 14, 647-650.

(8) Pagola, S.; Polla, G.; Leyva, G.; Casais, M.T.; Alonso, J.A.; Rasines, I.; Carbonio, R.E. Crystal structure refinement of $\mathrm{Ba}_{5} \mathrm{Nb}_{4} \mathrm{O}_{15-\mathrm{x}}$ by Rietveld analysis of neutron and X-ray diffraction data. Mat. Sci. Forum 1996, 228, 819-824.

(9) Kim, D. W.; Kim, J. R.; Yoon, S. H.; Hong. K. S. Microwave dielectric properties of low-fired $\mathrm{Ba}_{5} \mathrm{Nb}_{4} \mathrm{O}_{15}$. J. Am. Ceram. Soc., 2002, 85, 2759-2762.

(10) Zhuang, H.; Yue, Z.; Zhao, F.; Pei, J.; Li, L. Microstructure and microwave dielectric properties of $\mathrm{Ba}_{5} \mathrm{Nb}_{4} \mathrm{O}_{15}-\mathrm{BaWO}_{4}$ composite ceramics. J. Alloys Comp. 2009, 472, 411-415.

(11) Durif, A. Structure crystalline des orthovanadates et orthoarsenites de barium et de strontium. Acta Cryst. 1959, 12, 420421.

(12) Skakle, J. M. S.; Coats A. M.; Marr, J. The crystal structures of $\mathrm{Ba}_{2} \mathrm{R}_{2 / 3} \mathrm{~V}_{2} \mathrm{O} 8(\mathrm{R}=\mathrm{La}, \mathrm{Nd})$ and $\mathrm{Sr}_{2} \mathrm{La}_{2 / 3} \mathrm{~V}_{2} \mathrm{O}_{8}$; palmierite derivatives. J. Mat. Sci. 2000, 35, 3251-3256.

(13) Zachariasen, W. H. The crystal structure of the normal orthophosphates of barium and strontium. Acta Cryst. 1948, 1, 263265 .

(14) Darriet, J.; Subramanian, M. A. Structural relationships between compounds based on the stacking of mixed layers related to hexagonal perovskite-type structures. J. Mater. Chem. 1995, 5(4), 543-552.

(15) Macías, J.; Yaremchenko, A. A.; Frade J. R. Redox transitions in strontium vanadates: Electrical conductivity and dimensional changes. J. Alls. Comp. 2014, 6o1, 186-194.

(16) Leonidova; O.N.; Leonidova; E.I. Synthesis and electrophysical properties of cation conductors $\left.\mathrm{Sr}_{3-3 \mathrm{x}} \mathrm{La}_{2 \mathrm{x}}\left(\mathrm{V}_{1-\mathrm{y}} \mathrm{P}_{\mathrm{y}} \mathrm{O}_{4}\right)_{(2)}\right)$ with palmierite structure. Solid State Ionics 20o8, 179, 188-191.

(17) Leonidova, O.N.; Leonidova, E.I.; Fotiev, A. Charge transport in $\mathrm{M}_{3-3 \mathrm{x}} \mathrm{La}_{2 \mathrm{x}}\left(\mathrm{VO}_{4}\right)_{2}$ solid-solutions where $\mathrm{M}=\mathrm{Sr}$ or Ba. Sov. Electrochem. 1992, 28 1241-1247.

(18) Kemmler-Sack, S.; Treiber, U.; Fadini. A. Hexagonal perovskites with cationic vacancies. Z. Anorg. Allg. Chem. 1979, 453, 157162.

(19) Kemmler-Sack, S.; Treiber, U. Structure of rhombohedral 9L stacking polytypes. Z. Anorg. Allg. Chem. 1981, 478, 198-201.

(20) Brown-Holden, A. A.; Reedyk, M.; Garcia-González, E.; Parras, M.; González-Calbet, J.M. Raman scattering study of cation- 
deficient $\mathrm{Ba}_{-\mathrm{n}}(\mathrm{MoNb})_{\mathrm{n}-\delta} \mathrm{O}_{3 \mathrm{n}-\mathrm{x}}$ and related perovskite-like oxides. Chem. Mater. 2000, 12, 2287-2291.

(21) Garcia-González, E.; Parras M.; González-Calbet, J. M. A new structure model for $\mathrm{Ba}_{3} \mathrm{Nb}_{2} \mathrm{O}_{8}$ : A HREM study. Chem. Mater. 2000, 12, 2485-2489.

(22) Fop. S.; Skakle, J.M.S.; McLaughlin, A.C.; Connor, P.; Irvine, J.T.S.; Smith, R.I.; Wildman, E.J. Oxide ion conductivity in the hexagonal perovskite derivative $\mathrm{Ba}_{3} \mathrm{MoNbO}_{8.5}$ J. Amer. Chem. Soc. (accepted), 2016.

(23) Lacorre, P.; Goutenoire, F.; Bohnke, O.; Retoux, R.; Laligant, Y. Designing fast oxide-ion conductors based on $\mathrm{La}_{2} \mathrm{Mo}_{2} \mathrm{O}_{9}$. Nature, 2000, 404, 856-858.

(24) Abraham, F.; Debreuille-Gresse, M. F.; Mairesse, G.; Nowogrocki, G. Phase transitions and ionic conductivity in $\mathrm{Bi}_{4} \mathrm{~V}_{2} \mathrm{O}_{11}$ with a layered structure. Solid State Ionics, 1988, 30, 529532.

(25) Williams, W. G.; Ibberson, R. M.; Day, P.; Enderby, J. E.; GEM - General Materials Diffractometer at ISIS. Physica B 1997, 241, 234.

(26) Larson, A. C.; Von Dreele, R. B.; "General Structure Analysis System (GSAS)", Los Alamos National Laboratory Report LAUR, 2000 86-748.

(27) Toby, B.H. EXPGUI, a graphical user interface for GSAS. J. Appl. Cryst. 2001, 34, 210-213.

(28) Kunwar, A.C.; Turner, G.L.; Oldfield, E. Solid-state spinecho Fourier transform NMR of K-39 and Zn-67 salts at high field. J. Magn. Reson. 1986, 69, 124-127.

(29) Bodart, P. R.; Amoureux, J. P.; Dumazy, Y.; Lefort, R. Theoretical and experimental study of quadrupolar echoes for half-integer spins in static solid-state NMR. Mol. Phys. 2ooo, 98, 15451551 .

(30) Massiot, D.; Fayon, F.; Capron, M.; King, I.; Le Calvé, S.; Alonso, B.; Durand, J.O.; Bujoli, B.; Gan, Z.; Hoatson G. Modelling one- and two-dimensional solid-state NMR spectra. Magnetic Resonance in Chemistry, 200240 70-76.

(31) Bezjak, J.; Abakumov, A.M.; Recnik, A.; Krzmanc M.M.; Jancar B.; Suvorov, D. The local structure and composition of $\mathrm{Ba}_{4} \mathrm{Nb}_{2} \mathrm{O}_{9}$-based oxycarbonates. J. Solid State Chem. 2010, 183, 1823-1828.

(32) International Tables for X-ray Crystallography, Kynoch Press, Birmingham, 1965, Vol II, 342.

(33) Zhdanov, G. S. Dokl. Acad. Nauk. SSSR. 1945, 48, 40-43.

(34) LeBail, A., Duroy, H. \& Fourquet, J.L. Ab initio structure determination of $\mathrm{LiSbWO}_{6}$ by x-ray powder diffraction. Mat. Res. Bull. 1988, 23, 447-452.

(35) Katz, L.; Ward, R. Structure relations in metal oxides. Inorg. Chem. 1964, 3, 205-211.

(36) Shannon, R. D. Revised effective ionic-radii and systematic studies of interatomic distances in halides and chalcogenides. Acta Crystallographica. 1976, A32, 751-767.

(37) Van Tendeloo, G.; Amelinckx, S.; Darriet, B.; Bontchev, R.; Darriet, J.; Weil, F. Structural considerations and high resolution electron microscopy observations of $\mathrm{LaSn}_{-\delta} \mathrm{O}_{3 \mathrm{n}}$. J. Solid State Chem. 1994, 108, 314-335.

(38) Samoson, A. Satellite transition high-resolution NMR of quadrupolar nuclei in powders. Chem. Phys. Lett. 1985, 119, 29-32. (39) Jäger, C. NMR Basic Principles and Progress, Springer-Verlag, Berlin, 1994.

(40) Millot, Y.; Man, P. P. Procedures for labeling the high-resolution axis of two-dimensional MQ-MAS NMR spectra of half-integer quadrupole spins. Solid State Nucl. Magn. Reson. 2002, 21, 21-43.

(41) Anupõld, T.; Reinhold, A.; Sarv, P.; Samoson, A. A comparison of double rotation and multi-quantum magic angle spinning spectra. Solid State Nucl. Magn. Reson. 1998, 13, 87-91.

(42) Du, L. S.; Schurko, R. W.; Lim, K. H.; Grey, C. P. A solidstate Nb-93 and F-19 NMR spectroscopy and X-ray diffraction study of potassium heptafluoroniobate $(\mathrm{V})$ : Characterization of Nb-93, F-19 coupling, and fluorine motion. J. Phys. Chem. A 2001, 105, $760-768$.

(43) Grey, I.E.; Li, C.; Cranswick, L.M.D.; Roth, R.S.; Vanderah, T.A.; Structure analysis of the $6 \mathrm{H}-\mathrm{Ba}\left(\mathrm{Ti}_{1} \mathrm{Fe}_{3}+, \mathrm{Fe}_{4+}\right) \mathrm{O}_{3-\delta}$ solid solution. J. Solid State Chem., 1988, 135, 312-321.

(44) Sinclair, D. C.; Skakle, J. M. S.; Morrison, F. D.; Smith, R. I; Beales, T. P. Structure and electrical properties of oxygen-deficient hexagonal $\mathrm{BaTiO}_{3}$. J. Mater. Chem. 1999, 9, 1327-1331.

(45) Miranda, L.; Boulahya, K.; Hernando, M.; Sinclair, D. C.; Jiménez-Villacorta, F.; Varela, A.; González-Calbet, J. M.; Parras, M. Structure-Composition-Property Relationships of $6 \mathrm{H}-\mathrm{BaTi}_{1}$ ${ }_{\mathrm{y}} \mathrm{Co}_{\mathrm{y}} \mathrm{O}_{3-\delta}(0.1<=\mathrm{y}<=0.4)$. Chem. Mater. 2011, 23(4), 1050-106o.

(46) Jacobson, A. Powder neutron diffraction study of the structure and oxygen vacancy distribution in $6 \mathrm{H} \mathrm{BaFeO}_{2.79}$. J. Acta Cryst. 1976, B32, 1087-1090.

(47) Lee C. T.; Ou C. C.; Lin, Y. C.; Huang, C. Y.; Su, C. Y. Structure and microwave dielectric property relations in $\left(\mathrm{Ba}\left(_{1-\mathrm{x}}\right) \mathrm{Sr}\left(\mathrm{x}_{\mathrm{x}}\right.\right.$ ) ${ }_{5} \mathrm{Nb}_{4} \mathrm{O}_{15}$ system. J. Eur. Cer. Soc. 2007, 27, 2273-2280.

(48) Lee, C. T.; Chen, C. T.; Huang, C. Y.; Wang, C. J. Microwave dielectric properties of $\left(\mathrm{Ba}_{1-\mathrm{x}} \mathrm{Mg}_{\mathrm{x}}\right)_{5} \mathrm{Nb}_{4} \mathrm{O}_{15}\left(\mathrm{Ba}_{1-\mathrm{x}} \mathrm{Mg}_{\mathrm{x}}\right)_{5} \mathrm{Nb}_{4} \mathrm{O}_{15}$ ceramics. Jap. J. Appl. Phys. 2oo8, 47, 4634-4637.

(49) Miseki, Y,; Kato, H.; Kudo, A. Water splitting into $\mathrm{H}_{2}$ and $\mathrm{O} 2$ over niobate and titanate photocatalysts with (111) plane-type layered perovskite structure. Energy Environ. Sci., 2009, 2, 306-314 (50) Boulahya, K.; Amadon, I.; Parras, M.; Gonzalet-Calbet, J. M. The Oxycarbonate $\mathrm{Ba}_{3} \mathrm{CO}_{2}\left(\mathrm{CO}_{3}\right)_{0.60}$ with a $2 \mathrm{H}-\mathrm{ABO}_{3}$-Related Structure. Chem. Mater. 200o, 12, 966-972.

(51) Massa, N. E.; Pagola, S.; Carbonio, R. Far-infrared reflectivity and Raman spectra of $\mathrm{Ba}_{5} \mathrm{Nb}_{4} \mathrm{O}_{15}$. Phys. Rev. B. 1996, 53, 81488150.

(52) García-González, E., Parras, M. \& González -Calbet, J. M. Electron microscopy study of a new cation deficient perovskitelike oxide: $\mathrm{Ba}_{3} \mathrm{MoNbO}_{8.5}$. Chem. Mater. 1998, 10, 1576-1581.

(53) Jehng J.M.; Wachs I.E. Structural chemistry and Raman spectra of niobium oxides. Chem. Mater. 1991, 3, 100-107. 


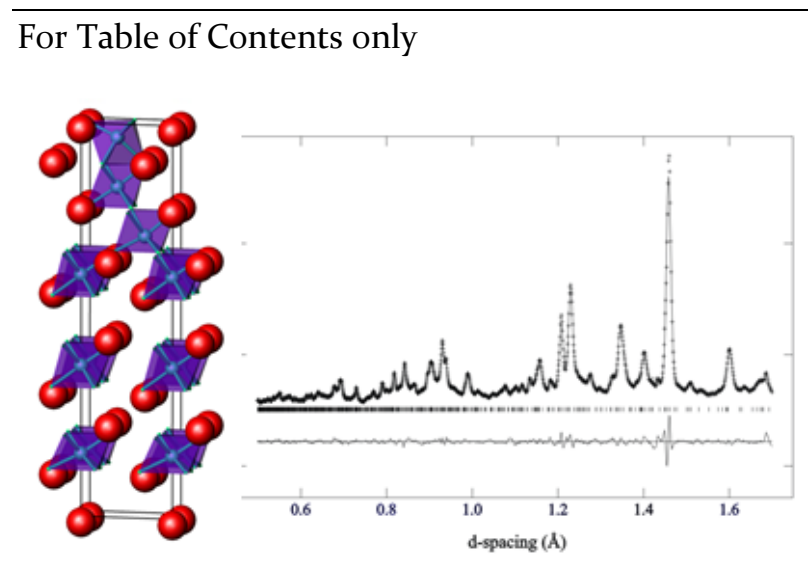

The structure of $\mathrm{Ba}_{3} \mathrm{Nb}_{2} \mathrm{O}_{8}$ is derived from the $9 \mathrm{R}$ perovskite structure, but with $\mathrm{Nb}$ occupying distorted and often oxygen deficient octahedral sites with oxygen vacancies between hexagonal close-packed $\mathrm{BaO}_{3-\delta}$ layers. Isolated, corner-sharing and face-sharing $\mathrm{Nb}-\mathrm{O}$ octahedra all occur within the unit cell, as confirmed by neutron diffraction and solid state ${ }^{93} \mathrm{Nb}$ wideline NMR measurements. 


\section{The crystal structure of $\mathrm{Ba}_{3} \mathrm{Nb}_{2} \mathrm{O}_{8}$ revisited: a neutron diffrac- tion and solid state NMR study.}

Eve J. Wildman ${ }^{\dagger}$, Abbie C. Mclaughlin ${ }^{\dagger}$, James F. Macdonald ${ }^{\ddagger}$ John V. Hanna ${ }^{\ddagger}$ and Janet M. S. Skaklet,\$*

${ }^{\dagger}$ Department of Chemistry, School of Natural \& Computing Sciences, University of Aberdeen, Meston Walk, Aberdeen $A B 243 U E, U K$

${ }^{\ddagger}$ Department of Physics, University of Warwick, Gibbet Hill Rd., Coventry CV4 $7 A L U K$

${ }^{\S}$ Department of Physics, School of Natural E Computing Sciences, University of Aberdeen, Meston Walk, Aberdeen $A B 243 U E, U K$.

Table S1: The derivation of Model 7. The grey layers highlight layers from Model 3 and 6 that possessed realistic bond lengths and were subsequently inserted into Model 7.

\begin{tabular}{|c|c|c|}
\hline Model 3 & Model 6 & $\begin{array}{l}\text { "Hybrid" } \\
\text { model } 7\end{array}$ \\
\hline A & A & A \\
\hline B & B & B \\
\hline C & C & $C$ \\
\hline B & A & B \\
\hline $\mathrm{C}$ & $\mathrm{C}$ & $\mathrm{C}$ \\
\hline B & A & B \\
\hline $\mathrm{C}$ & $\mathrm{B}$ & $\mathrm{C}$ \\
\hline B & A & A \\
\hline $\mathbf{C}$ & B & $\mathrm{B}$ \\
\hline
\end{tabular}


Table $\mathrm{S}_{2} \mathrm{Ba}-\mathrm{O}$ bond lengths in $\mathrm{Ba}_{3} \mathrm{Nb}_{2} \mathrm{O}_{8}$ according to model 7 .

\begin{tabular}{|c|c|}
\hline Ba-O Bond & Bond Length $(\AA)$ \\
\hline $\mathrm{Ba}(1)-\mathrm{O}(1) \times 6$ & $2.970(2)$ \\
\hline $\mathrm{O}(2) \times 3$ & $3.31(2)$ \\
\hline $\mathrm{O}(9) \times 3$ & $2.8 \mathrm{o}(2)$ \\
\hline $\mathrm{Ba}(2)-\mathrm{O}(1) \times 3$ & $2.69(2)$ \\
\hline $\mathrm{O}(2) \times 6$ & $3.000(5)$ \\
\hline $\mathrm{O}(3) \times 3$ & $3.08(2)$ \\
\hline $\mathrm{Ba}(3)-\mathrm{O}(2) \times 3$ & $2.87(2)$ \\
\hline $\mathrm{O}(3) \times 6$ & $2.976(4)$ \\
\hline $\mathrm{O}(4) \times 3$ & $2.68(2)$ \\
\hline $\mathrm{Ba}(4)-\mathrm{O}(3) \times 3$ & $2.559(2)$ \\
\hline $\mathrm{O}(4) \times 6$ & $2.990(4)$ \\
\hline $\mathrm{O}(5) \times 3$ & $3 \cdot 34(2)$ \\
\hline $\mathrm{Ba}(5)-\mathrm{O}(4) \times 3$ & $2.90(2)$ \\
\hline $\mathrm{O}(5) \times 6$ & $2.9563(11)$ \\
\hline $\mathrm{O}(6) \times 3$ & $3.22(2)$ \\
\hline $\mathrm{Ba}(6)-\mathrm{O}(5) \times 3$ & $2.96(2)$ \\
\hline $\mathrm{O}(6) \times 6$ & $2.9720(17)$ \\
\hline $\mathrm{O}(7) \times 3$ & $3.02(2)$ \\
\hline $\mathrm{Ba}(7)-\mathrm{O}(6) \times 3$ & $2.90(2)$ \\
\hline $\mathrm{O}(7) \times 6$ & $2.979(4)$ \\
\hline $\mathrm{O}(8) \times 3$ & $3.15(3)$ \\
\hline $\mathrm{Ba}(8)-\mathrm{O}(7) \times 3$ & $2.81(2)$ \\
\hline $\mathrm{O}(8) \times 6$ & $2.9551(5)$ \\
\hline $\mathrm{O}(9) \times 3$ & $2.68(2)$ \\
\hline $\mathrm{Ba}(9)-\mathrm{O}(1) \times 3$ & $2.87(2)$ \\
\hline $\mathrm{O}(8) \times 6$ & 2.88(3) \\
\hline $\mathrm{O}(9) \times 3$ & $2.968(4)$ \\
\hline
\end{tabular}


Table $\mathrm{S}_{3} \mathrm{O}-\mathrm{Nb}-\mathrm{O}$ bond angles in $\mathrm{Ba}_{3} \mathrm{Nb}_{2} \mathrm{O}_{8}$ according to model 7 . All show a distorted Nb-O environment.

\begin{tabular}{|c|c|}
\hline $\mathrm{O}-\mathrm{Nb}-\mathrm{O}$ & Angle (o) \\
\hline $\mathrm{O}(2)-\mathrm{Nb}(1)-\mathrm{O}(2)$ & $95 \cdot 7(8)$ \\
\hline \multirow[t]{2}{*}{$\mathrm{O}(2)-\mathrm{Nb}(1)-\mathrm{O}(3)$} & $178.2(10)$ \\
\hline & $83.1(3)$ \\
\hline $\mathrm{O}(3)-\mathrm{Nb}(1)-\mathrm{O}(3)$ & $82.9(10)$ \\
\hline $\mathrm{O}(4)-\mathrm{Nb}(2)-\mathrm{O}(4)$ & $82.9(10)$ \\
\hline \multirow[t]{2}{*}{$\mathrm{O}(4)-\mathrm{Nb}(2)-\mathrm{O}(5)$} & $171.2(14)$ \\
\hline & $90.5(6)$ \\
\hline $\mathrm{O}(5)-\mathrm{Nb}(2)-\mathrm{O}(5)$ & $95 \cdot 4(12)$ \\
\hline $\mathrm{O}(6)-\mathrm{Nb}(3)-\mathrm{O}(6)$ & $78.6(11)$ \\
\hline \multirow{2}{*}{$\mathrm{O}(6)-\mathrm{Nb}(3)-\mathrm{O}(7)$} & $171.5(11)$ \\
\hline & $94.9(5)$ \\
\hline $\mathrm{O}(7)-\mathrm{Nb}(3)-\mathrm{O}(7)$ & $91.0(8)$ \\
\hline $\mathrm{O}(7)-\mathrm{Nb}(4)-\mathrm{O}(7)$ & $110.5(5)$ \\
\hline \multirow{2}{*}{$\mathrm{O}(7)-\mathrm{Nb}(4)-\mathrm{O}(8)$} & $153.2(8)$ \\
\hline & $83.6(4)$ \\
\hline $\mathrm{O}(8)-\mathrm{Nb}(4)-\mathrm{O}(8)$ & $75 \cdot 3(6)$ \\
\hline $\mathrm{O}(8)-\mathrm{Nb}(5)-\mathrm{O}(8)$ & $95.0(8)$ \\
\hline \multirow[t]{2}{*}{$\mathrm{O}(8)-\mathrm{Nb}(5)-\mathrm{O}(9)$} & $179.0(12)$ \\
\hline & $84 \cdot 3(4)$ \\
\hline $\mathrm{O}(9)-\mathrm{Nb}(5)-\mathrm{O}(9)$ & $96.4(10)$ \\
\hline $\mathrm{O}(1)-\mathrm{Nb}(6)-\mathrm{O}(1)$ & $100.8(9)$ \\
\hline \multirow[t]{2}{*}{$\mathrm{O}(1)-\mathrm{Nb}(6)-\mathrm{O}(9)$} & $162.4(10)$ \\
\hline & $90.3(6)$ \\
\hline $\mathrm{O}(9)-\mathrm{Nb}(6)-\mathrm{O}(9)$ & $75 \cdot 9(8)$ \\
\hline
\end{tabular}



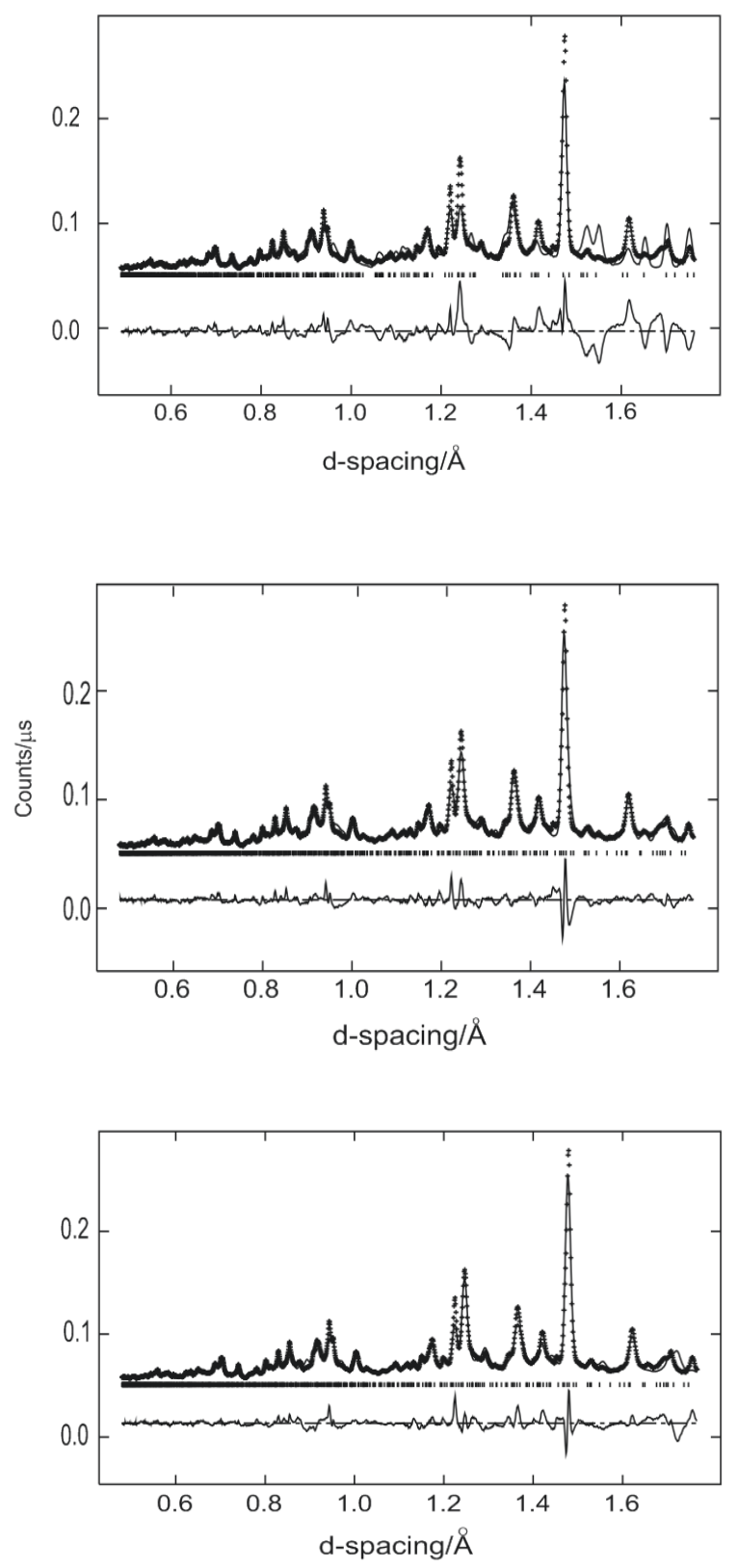

Figure S1 Rietveld refinement of $\mathrm{Ba}_{3} \mathrm{Nb}_{2} \mathrm{O} 8$ neutron diffraction data, using (top) the palmierite model, (middle) model 3 (ccchhhhhh), (bottom) model 6 (cchhchhhh). The resultant fits are of the high angle bank (1540). 